\title{
Bioactive dihydroxyfuranonaphthoquinones from the bark of Tabebuia incana A.H. Gentry (Bignoniaceae) and HPLC analysis of commercial pau d'arco and certified T.incana

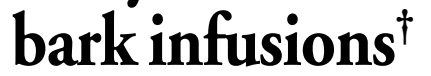

\author{
Sabrina Kelly Reis de MORAIS, ${ }^{1}$ Suniá Gomes SILVA, ${ }^{1}$ Cíntia Nicácio PORTELA, ${ }^{2}$ Sergio Massayoshi \\ NUNOMURA, ${ }^{2}$ Etienne Louis Jacques QUIGNARD, ${ }^{2}$ Adrian Martin POHLIT.,

\begin{abstract}
Tabebuia incana A.H. Gentry (Bignoniaceae) is a tree from the Brazilian Amazon having medicinal uses and is one several Tabebuia spp. known as pau d'arco or palo de arco in this region. Fractionation of the bark ethanolic extract afforded a mixture of 5 and 8 hydroxy-2-(1-hydroxyethyl)naphtho[2,3-b] furan-4,9-diones (1 and 2, respectively) identified on the basis of nuclear magnetic resonance (NMR), infrared (IR) and mass (MS) spectra, whose in vitro antimalarial and antitumor activity have been shown previously. This is the first study on T. incana bark, and 2 are described in this species for the first time. Also, high performance liquid chromatography (HPLC) analysis of $T$. incana bark tea revealed the presence of the $1+2$ mixture peak corresponding to a concentration in the range $10^{-6}-10^{-5} \mathrm{M}$. The chromatograms of teas prepared from commercial pau d'arco and T. incana bark were
\end{abstract} \\ also studied and the presence of the $1+2$ peak has potential for quality control of commercial plant materials.
}

\section{KEYWORDS}

Artemia franciscana Leach, 5-hydroxy-2-(1-hydroxyethyl)naphtho[2,3-b]furan-4,9-dione, 8-hydroxy-2-(1hydroxyethyl)naphtho[2,3-b]furan-4,9-dione.

\section{Diidroxifuranonaftoquinonas bioativas das cascas de Tabebuia incana A.H. Gentry (Bignoniaceae) e análise por CLAE de infusões de cascas de pau d'arco comercial $\mathrm{T}$ T. incana certificada}

\section{RESUMO}

Tabebuia incana A.H. Gentry (Bignoniaceae) é uma árvore da Amazônia brasileira com usos medicinais. É uma de várias espécies de Tabebuia conhecidas como pau d'arco ou palo de arco nesta região. O fracionamento do extrato etanólico das cascas resultou no isolamento da mistura de 5 e 8-hidróxi-2-(1-hidroxietil)nafto[2,3-b]furano-4,9-dionas (1 e 2, respectivamente), identificadas com base em seus espectros de ressonância magnética nuclear (RMN), infravermelho (IV) e massa (EM), e cujas atividades antimalárica e antitumoral in vitro foram mostradas previamente. Este éo primeiro estudo das cascas de $\mathrm{T}$. incana e a primeira vez que o composto 2 é descrito nesta espécie. Análises por cromatografia liquida de alto empenho (CLAE) do chá das cascas de $\mathrm{T}$. incana revelaram a presença de um pico correspondente à mistura de $1+2$, permitindo inferir uma concentração na faixa de $10^{-6}-10^{-5} \mathrm{M}$ desses componentes no chá. Os cromatogramas de chás (infusöes) preparados a partir das cascas de pau d'arco commercial and T. incana certificada também foram estudados. A verficação da presença do pico das substâncias $1+2$ nos cromatogramas tem potencial contribuição para o controle de qualidade de material vegetal comercial.

\section{PALAVRAS-CHAVE}

Artemia franciscana Leach, 5-hydroxy-2-(1-hydroxyethyl)naphtho[2,3-b]furan-4,9-dione, 8-hydroxy-2-(1-hydroxyethyl)naphtho[2,3b]furan-4,9-dione.

\footnotetext{
1 Instituto de Ciências Exatas, Universidade Federal do Amazonas (UFAM), Av. General Rodrigo Otávio Jordão Ramos, 3000, 69077-000 Manaus, Amazonas; ${ }^{2}$ Coordenação de Pesquisas em Produtos Naturais (CPPN), Instituto Nacional de Pesquisas da Amazônia (INPA), Av. André Araújo, 2936, 69083-000 Manaus, Amazonas. ${ }^{\dagger}$ This work was partially presented in the Master's Dissertation by Sabrina Kelly Reis de Morais (2003).

‡Author to whom correspondence should be addressed (e-mail: ampohlit@inpa.gov.br).
} 


\section{INTRODUCTION}

Tabebuia incana is an Amazonian tree, popularly known as "ipê amarelo" and "pau d'arco" (Silva et al., 1977; Oliveira et al., 1993). Pau d'arco bark tea is used by the local population for the treatment of inflammation, malaria, cancer, kidney and liver disorders (Silva et al., 1977). In previous reports, only the trunkwood has been studied and prenylnaphthoquinones predominate among the isolated compounds. Thus, furanonaphthoquinones, such as (-)-1 (Figure 1), the dehydrofuranonaphthoquinones dehydro-5-hydroxy-iso-alapachone and dehydro-iso-a-lapachone, together with lapachol, lapachenol, tecomaquinone I, and the lignans cycloolivil and pawlownin are all known components of the trunkwood (Oliveira et al., 1990; Oliveira et al., 1993).

In our previously published screenings on the cytotoxicity of Amazonian plant extracts towards the brine shrimp larva species Artemia franciscana, bark water extracts of T. incana were found to be inactive and methanol extracts showed moderate lethality (Quignard et al., 2003; Quignard et al., 2004). Also, bark methanol extracts were completely inactive to the larvae of the insect species Aedes aegypti, the hemorrhagic dengue fever vector (Pohlit et al., 2004). In this report, a mixture of furanonaphthoquinones 1 and 2 was isolated from the bark of T. incana and these compounds were detected in bark teas using High Performance Liquid Chromatography (HPLC).

\section{MATERIAL AND METHODS}

\section{PHYTOCHEMICAL STUDY}

T. incana bark was collected from a previously catalogued individual at INPA's Ducke Forest Reserve (Manaus) in January, 2001. A voucher specimen is deposited in the INPA Herbarium under the number 23866 and was identified by A. H. Gentry. Dried, milled bark $(1.3 \mathrm{~kg})$ was macerated in ethanol $(2-7$ days) and the extract (46.8 g, 3.6\%) was obtained after filtration and total evaporation. A portion of this extract $(44.3 \mathrm{~g}$ ) was suspended in methanol-water and partitioned in increasingly polar solvents, yielding, after total evaporation, to hexane (4.4 $\mathrm{g})$, chloroform $(11.1 \mathrm{~g})$ and methanol-water $(27.2 \mathrm{~g})$ fractions. The chloroform fraction $(8.85 \mathrm{~g})$ was chromatographed on a column of silica gel $60(63-210 \mathrm{~mm})$ using a chloroformmethanol gradient as eluent, providing 4 sub-fractions. Sub-
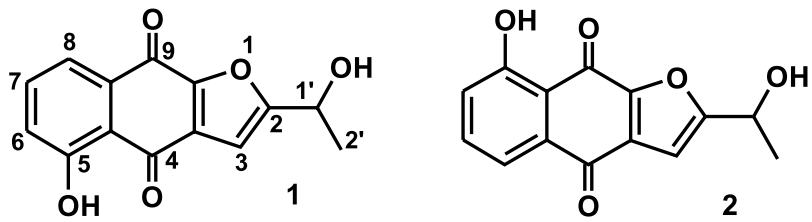

Figure 1 - Structures of the furanonaphthoquinones isolated as a mixture from Tabebuia incana bark ethanol extract. fractions $2(82 \mathrm{mg})$ and $3(2.2 \mathrm{~g})$ were separately fractionated by normal phase preparative thin-layer chromatography (TLC, eluents: hexane-ethyl acetate) and by two sequential, normal phase column chromatographic separations, respectively. Subfractions obtained from these procedures were combined (53.1 $\mathrm{mg}$ ) based on TLC and submitted to reverse-phase column chromatography (acetonitrile-acetic acid-water), affording a mixture of compounds 1 and $2(6.5 \mathrm{mg}, 0.015 \%$ based on extract).

Mixtures of 1 and 2 are known to be unseparable on silica gel. The only known separation was performed by Fujimoto $e t$ al. (1991) who synthesized a mixture of ( \pm )-1 and ( \pm )-2 and achieved separation by first derivatizing as the myristoyl diesters, followed by normal phase chromatographic separation, and finally by saponification. Such separation was beyond the scope of this work due to, among other reasons, the low yield of the 1 + 2 mixture isolated from T. incana bark.

\section{5- AND 8-HYDROXY-2-(1-HYDROXYETHYL)NAPHTHO[2,3- B]FURAN-4,9-DIONES (1 AND 2)}

This mixture was obtained as a yellow amorphous powder which presented the following spectral data: IR $(\mathrm{KBr}) \mathrm{n}_{\text {max }} \mathrm{cm}^{-1}$ 3424, 3123, 2925, 1673, 1641, 1596, 1534; MS (70 eV) m/ $z$ (rel. int.) 258 [M] $^{+}(79), 243$ (100), 215 (45), 221 (25), 187 (23), 63 (26), 43 (33); ${ }^{1} \mathrm{H}$ NMR (200 MHz, CDCl, TMS) ä $12.18(\mathrm{~s}, 1 \mathrm{H}, 5-\mathrm{OH}), 12.03(\mathrm{~s}, 1 \mathrm{H}, 8-\mathrm{OH}), 7.75(\mathrm{~m}, 2 \mathrm{H})$, $7.61(\mathrm{~m}, 2 \mathrm{H}), 7.29$ (m, 2H), 6.85 (bs, 1H), 6.84 (bs, 1H), $5.05(\mathrm{q}, J=6.6 \mathrm{~Hz}, 2 \mathrm{H}), 1.8$ (bs, 2H, $\left.1^{\prime}-\mathrm{OH}\right), 1.66$ (d, $J=6.6$ $\mathrm{Hz}, 6 \mathrm{H})$.

\section{BIOLOGICAL ASSAY}

Extract, fractions obtained from partition, chromatographic fractions and the isolated mixture were tested for lethality in the brine shrimp assay using Artemia franciscana larvae (McLaughlin et al. 1991; Meyer et al., 1982). The dose-response curve was generated by submitting log concentration and lethality data to probit analysis, from which median lethal concentrations $\left(\mathrm{LC}_{50}\right)$

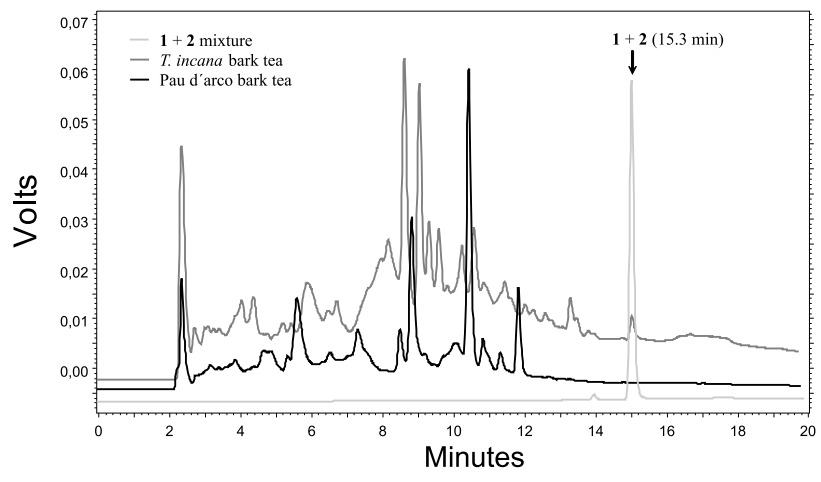

Figure 2 - HPLC chromatograms of pau d'arco bark teas and $\mathbf{1}+\mathbf{2}$ sample. 
and standard deviation were obtained, according to the method described by Litchfield and Wilcoxon (1949).

\section{PREPARATION OF T. incana AND PAU D'ARCO BARK TEA (INFUSION)}

Medicinal herb sellers at the Adolpho Lisboa Municipal Market in Manaus's downtown provided information on the preparation (proportion of water to plant material, infusion method) of pau d'arco bark tea: milled bark (17 g) was infused in de-ionized water $\left(100^{\circ} \mathrm{C}, 500 \mathrm{ml}, 20 \mathrm{~min}\right)$ and after filtration the filtrate (tea) was stored in a freezer. Thus, bark teas were prepared using commercial pau d'arco samples as well as T. incana collected and identified in our study.

\section{HPLC ANALYSIS OF T. incana AND PAU D’ARCO BARK TEAS.}

HPLC was performed using a Shimadzu LC-10AT Liquid Chromatograph (SPD-10A UV-vis Detector, DGU-14A Degasser, FCV-10L Mixer, SCL System Controller, Rheodyne (manual) injector valve, $10 \mathrm{ml}$ sample loop, and Shim-Pack CLCODS column $(250 \times 4.6 \mathrm{~mm}, 5$ ìm particle size $)$. Chromatographic analysis was performed under the following conditions: flow rate: $1.0 \mathrm{ml} \times \mathrm{min}^{-1}$, mobile phase: $\mathrm{MeOH} /$ $\mathrm{H}_{2} \mathrm{O} 45: 55$ (0 min), linear gradient to 80:20 (10 $\left.\mathrm{min}\right)$, then isocratic until end of run $(20 \mathrm{~min})$, detection at $\mathrm{l}=254 \mathrm{~nm} .30$ min equilibration time was used. T. incana and pau d'arco bark teas, as well as the $1+2$ mixture, were analyzed and the resulting chromatograms are presented in Figure 2.

In an attempt to provide an estimate for the quantity of the mixture in T. incana tea, and given that pure 1 and 2 were not obtainable, the $T$. incana bark tea and the 2:1 mixture of 1 and 2 (at concentrations of 1,2 and $4 \mathrm{mg}^{-\mathrm{l}^{-1}}$ ) were analyzed in triplicate (Table 1) under the same chromatographic conditions as used to generate the chromatograms in Figure 2. A calibration curve was established from which the approximate concentration of the $\mathbf{1}+\mathbf{2}$ mixture in the bark tea was established using linear regression analysis (Figure 3). It was assumed based on Fujimoto et al. (1991) UV data (which included molar extinction coefficients for both 1 and 2) that the molar extinctions at 254 $\mathrm{nm}$ (detector wavelength) of 1 and 2 differ by an order of

Table 1 - Calibration and tea peak areas corresponding to $1+2$ mixture.

\begin{tabular}{cccc}
\hline $\begin{array}{c}\text { Standard Solution } \\
(\mathrm{mg} / \mathrm{L})\end{array}$ & Peak Areas & Avg. Peak Areas & SD \\
\hline \multirow{2}{*}{1} & 38507 & 36709 & 2213 \\
& 37382 & & \\
2 & 34237 & 70807 & \\
& 79265 & & \\
& 69553 & 150238 & 7983 \\
4 & 63604 & & \\
& 157603 & 34215 & 150 \\
\hline & 151355 & & \\
\hline
\end{tabular}

Peak areas refer to peak with $t_{R}=15.3$ min (3 repetitions). magnitude more or less, so that the T. incana tea prepared can be presumed to be $10^{-6}-10^{-5} \mathrm{M}$ in 1 and / or 2 .

\section{RESULTS AND DISCUSSION}

The existence of isomers in the isolated mixture was evidenced by the chemical shifts of the peri hydroxyl groups of 1 (d 12.18) and 2 ( 12.03) in the ${ }^{1} \mathrm{H}$ NMR spectrum. As pointed out by Wagner et al. (1989), this is the only conspicuous spectroscopic difference between these isomers. Moreover, the ${ }^{1} \mathrm{H}$ NMR spectrum presented signals in pairs, with different intensities, indicating the presence of constitutional isomers. The relative intensity / integrals of signals suggested the proportion of 1 and 2 to be $c a$. 2:1. The IR spectrum exhibited absorptions at 1673 and $1641 \mathrm{~cm}^{-1}$ due to carbonyl stretching characteristic of naphthoquinones, while the mass spectrum presented a $[\mathrm{M}]^{+}$ peak with $m / z 258$, compatible with the molecular formula $\mathrm{C}_{14} \mathrm{H}_{10} \mathrm{O}_{5}$ of 1 and 2. ${ }^{1} \mathrm{H}$ NMR data for 1 and 2 have been reported (Fujimoto et al., 1991). Our ${ }^{1} \mathrm{H}$ NMR data for the $1+$ 2 mixture were in general consistent with the previously reported data.

Mixtures of these two compounds have been isolated from T. ochracea ssp. neochrysantha (Pérez et al., 1997) and T. avellanedae (Fujimoto et al., 1991) bark and have been shown to possess important activity against rodent and human malaria parasites Plasmodium berghei and P. falciparum (Pérez et al., 1997), respectively. Also, compound 1 , extracted from dry T. avellanedae bark, is active in vitro against several types of malignant tumor cells and was patented in Japan in 1994 (Derwent, 2006). Furanonaphthoquinone 2, isolated from T. barbata bark, was significantly cytotoxic against A-549 human lung adenocarcinoma, MCF-7 human breast carcinoma, and HT-29 human colon carcinoma cells (Saizarbitoria et al., 1997).

Lethality in the brine shrimp assay has been correlated with in vitro antitumor activity in general and this assay is considered an important pre-screen for biomonitored isolation of cytotoxic compounds and anticancer drug research (McLaughlin et al., 1991). The ethanol extract and its chloroform fraction showed significant lethality $\left(\mathrm{LC}_{50} 167 \pm 39\right.$ and $12 \pm 4 \mathrm{mg} \cdot \mathrm{ml}^{-1}$, respectively) towards brine shrimp larvae, however, hexane and water-methanol fractions were inactive. These results show that during partition, cytotoxicity was concentrated solely in the

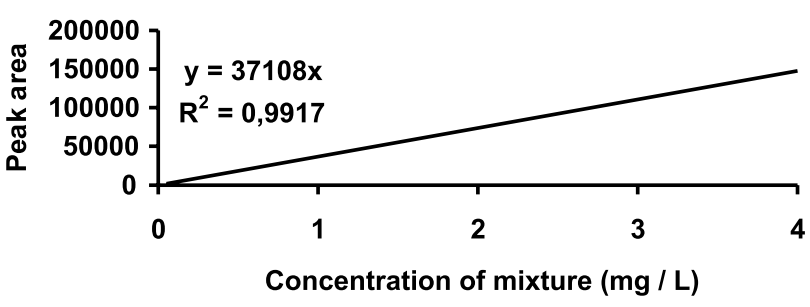

Figure 3 - Linear regression analysis of peak area vs. [mixture $1+2$ ] 
fraction of intermediate polarity. The isolated mixture of 1 and 2 was about as active $\left(\mathrm{LC}_{50} 15 \pm 10 \mathrm{mg} \cdot \mathrm{ml}^{-1}\right)$ as the chloroform fraction (from which this mixture was isolated) towards brine shrimp consistent with the existence of other cytotoxic components in the chloroform fraction.

Despite published studies on more than 20 Tabebuia spp., furanonaphthoquinone $\mathbf{1}$ has so far only been reported in $T$. avellanadae, T. chrysotricha, T. incana, T. ochracea and T. rosea, while 2 has been found in T. barbata, T. cassinoides, T. ochracea and (given the results presented above) T. incana (Morais, 2003).

Under the HPLC conditions developed, pau d'arco bark teas presenting $1+2$ are readily distinguished from those in which these compounds are absent. The HPLC chromatogram of the $T$. incana bark tea (Figure 2) reveals the $1+2$ mixture peak at $\mathrm{t}_{\mathrm{R}} 15.3 \mathrm{~min}$. Given that pau d'arco (palo de arco) is among the most important Amazonian plants sold in European markets, it is conceivable that HPLC analysis using $\mathbf{1}$ and $\mathbf{2}$ as (bio)markers may be important for quality control and the distinction of $T$. incana from other species which are also commercialized using the name pau d'arco, such as T. serratifolia. Also, the presence of antitumor and antimalarial compounds 1 and 2 in T. incana bark teas lends support to the traditional use of this plant in the treatment of tumors and malaria.

\section{CONCLUSION}

The isolated compounds have potential in quality control as marker substances for the pau d'arco species T. incana and may have use in the detection of adulterated or false plant materials.

\section{ACKNOWLEDGEMENTS}

The authors acknowledge the financial support of CNPq/ PNOPG (grant numbers 520354/99-0 and 550260/01-3) and the Bioamazônia/BASA/FEPAD contract, as well as scholarships from FAPEAM (SKRM) and CNPq (SGS, SMN, ELJQ).

\section{LITERATURE CITED}

Derwent, 2006. Thomson Derwent. http://thomsonderwent.com, accessed in December, 2006.

Fujimoto, Y.: Eguchi, T.; Murasaki, C.; Ohashi, Y.; Kakinuma, K.; Takagaki, H.; Abe, M.; Inazawa, K.; Yamazaki, K.; Ikekawa, N.; Yoshikawa, O.; Ikekawa, T. 1991. Studies on the structure and stereochemistrty of cytotoxic furanonaphthoquinones from Tabebuia impetiginosa: 5- and 8-hydroxy-2-(1hydroxyethyl)naphtho[2,3-b]furan-4,9-diones. J. Chem. Soc. Perkin Trans., 1(10): 2323-2327.

Litchfield, J.T.; Wilcoxon, F. 1949. A simplified method of evaluating dose-effect experiments. J. Pharmacol. Exp. Ther, 96(2): 99113.

McLaughlin, J.L.; Chang, C.J.; Smith, D.L. 1991. "Bench-top" bioassays for the discovery of bioactive natural products: an update. In: Rhaman, A.U. (ed.). Studies in Natural Product Chemistry, v. 8, Elsevier, Amsterdam.
Meyer, B.N.; Ferrigni, N.R.; Putnam, J.E.; Jacobsen, L.B.; Nichols, D.E.; McLaughlin, J.L. 1982. Brine shrimp: a convenient general bioassay for active plant constituents. Planta Medica, 45:31-34.

Morais, S.K.R. 2003. Estudo fitoquimico e atividade biológica das cascas de Tabebuia incana A.H. Gentry (Bignoniaceae). Dissertação de Mestrado, Universidade Federal do Amazonas, Manaus, Amazonas. 126pp.

Oliveira, A.B.; Raslan, D.S.; Miraglia, M.C.M.; Mesquita, A.A.L.; Zani, C.L.; Ferreira, D.T.; Maia, J.G.S. 1990. Chemical structures and biological activities of naphthoquinones from Brazilian Bignoniaceae. Quim. Nova, 13(4): 302-307.

Oliveira, A.B.; Raslan, D.S.; Oliveira, G.G.; Maia, J.G.S. 1993. Lignans and naphthoquinones from Tabebuia incana. Phytochemistry, 34(5): 1409-1412.

Pérez, H.; Diaz, F.;Medina, J.D. 1997. Chemical investigation and in vitro antimalarial activity of Tabebuia ochracea ssp. neochrysantha. Int. J. Pharmacogn., 35(4): 227-231.

Pohlit, A.M.; Quignard, E.L.J.; Nunomura, S.M.; Tadei, W.P.; Hidalgo, A.F.; Pinto, A.C.S.; Santos, E.V.M.; Alecrim, A.M.; Ferraz, A.B.; Pedroso, A.C.S.; Diniz, E.V.; Finney, E.K.; Gomes, E.O.; Don, L.C.; Queiroz, M.M.A.; Henrique, M.C.; Santos, M.; Lacerda Junior, O.S.; Pinto, P.S.; Silva, S.G.; Graça, Y.R. 2004. Screening of plants found in Amazonas State, Brazil for activity against Aedes aegypti larvae. Acta Amazonica, 34(1): $97-$ 105.

Quignard, E.L.Q.; Pohlit, A.M.; Nunomura, S.M.; Pinto, A.C.S.; Santos, E.V.M.; Morais, S.K.R.; Alecrim, A.M.; Pedroso, A.C.S.; Cyrino, B.R.B.; Melo, C.S.; Finney, E.K.; Gomes, E.O.; Souza, K.S.; Oliveira, L.C.P.; Don, L.C.; Silva, L.F.R.; Queiroz, M.M.A.; Henrique, M.C.; Santos, M.; Pinto, P.S.; Silva, S.G. 2003. Screening of plants found in Amazonas State for lethality towards brine shrimp. Acta Amazonica, 33(1): 93-104.

Quignard, E.L.Q. Nunomura, S.M.; Pohlit, A.M.; Alecrim A.M.; Pinto, A.C.S.; Portela, C.N.; Oliveira, L.C.P.; Don, L.C.; Rocha e Silva, L.F.R.; Henrique, M.C.; Santos, M.; Pinto, P.S.; Silva, S.G. 2004. Median Lethal Concentrations of Amazonian Plant Extracts in the Brine Shrimp Assay. Pharmaceutical Biology, 42(3): 253-257.

Saizarbitoria, T.C.; Anderson, J.E.; Alfonso, D.; Mclaughlin, J.L.. 1997. Bioactive furonaphthoquinones from Tabebuia barbata (Bignoniaceae). Acta Cient. Venez., 48(1): 42-46.

Silva, M.F.; Lisboa, P.L.B.; Lisboa, R.C.L. 1977. Nomes Vulgares de Plantas Amazônicas. INPA/CNPq, Manaus, Amazonas. 222pp.

Wagner, H.; Kreher, B.; Lotter, H.; Hamburger, M.O.; Cordell, G.A. 1989. Structure determination of new isomeric naphtho[2,3b] furan-4,9-diones from Tabebuia avellanedae by the selectiveINEPT technique. Helv. Chim. Acta, 72(4): 659-667.

Recebido em 30/07/2004

Aceito em 02/01/2007 